\title{
ACTIVITIES IN NATURE: HOW FREQUENT IS THE CONTACT OF CONTEMPORARY CHILDREN WITH THE NATURAL WORLD?
}

\author{
A. Almeida ${ }^{1}$, V. Rato ${ }^{2}$, Z.F. Dabaja ${ }^{3}$ \\ ${ }^{1}$ IInstituto Politécnico de Lisboa (IPL), CICS.NOVA (PORTUGAL) \\ ${ }^{2}$ Centro Indisciplinar de Estudo Educacionais, ESELx (PORTUGAL) \\ ${ }^{3}$ Master of Education, Freelance Researcher (LEBANON)
}

\begin{abstract}
The progressive process of industrialization occurring in the world in the last 200 years has increased the urban population. One of its consequences has been the gradual detachment from nature, which negatively affects children's development. At the same time, several authors state that children play essentially indoors, and outdoor activities are declining not only in nature places but also in urban areas, due to several reasons.

The present study aims to check how frequently a myriad of several outdoor activities are performed by a group of 153 urban children, 87 boys and 70 girls, from 6 state primary schools with different social backgrounds (low to high socio-economic status) from the Lisbon area. Differences between boys and girls were also analysed. For this purpose, a questionnaire was administered containing demographic-related items, such as sex, age and school, and the following 11 statements pertaining to different outdoor activities: picking up wild fruits; gardening; climbing trees; catching birds in traps; collecting rocks, minerals and fossils; tracking; visiting farms, zoos and other thematic parks; practising outdoor sports; playing in forested areas; going hunting or fishing with friends and relatives; rappelling and other extreme sports. Children had to select the frequency of their performing of each activity on a four-point scale. A total score for the 11 activities was also calculated.
\end{abstract}

The results show that almost all activities have never or rarely been done by the participants, and only outdoor sports are practised more often (sometimes). Boys and girls statistically significant differences were only for practising outdoor sports and for hunting and fishing with friends and relatives, favouring boys. But the frequency of this latter activity was very low in both genders.

The present study confirmed children's prevalent disconnection with nature alongside the decline in performing different outdoor activities, showing that this trend is at least affecting several western countries. Since the situation is impoverishing children's development and affecting their knowledge and awareness about the importance of the natural world, implications for parents, teachers and policy makers are discussed to try to invert the present trend.

Keywords: Primary children, Contact with nature, Outdoor activities.

\section{INTRODUCTION}

The progressive process of industrialization that has been occurring in the world in the last 200 years has increased urban population and has decreased nature areas. Nowadays, about $55 \%$ of the world's population lives in urban settings. This figure is expected to increase to $68 \%$ by 2050 ([1] United Nations, 2018). This reality has been affecting the relationship between the human being and nature. According to [2] [3] Kellert $(1997,2005)$, direct contact with natural or semi-natural places is declining; in opposition, contact with places where nature is managed by humans, such as zoos, botanic gardens or urban parks, has increased in relative terms. Consequently, [4] Clements (2004) proposed that children, nowadays, are spending considerably less time in contact with nature when compared to their parents when they were children.

Although nature parks are still important places of visitation around the world, and these protected areas have been increasing in number in the last decades ([5] UNEP-WCMC), yet, it is suggested that, in many cases, the outdoor experiences within these areas might not always be occurring in a way that permits an immersion in nature. In a Portuguese context, [6] Cian Cavagna \& Zoccoli (2001) state that many trips to protected areas are made by car or bus, without much interaction with nature. Therefore, it seems that the departure from nature is happening not only in quantitative but also in qualitative terms. 
It also appears that children are disconnecting not only from the wild natural areas, but also from places where nature is managed by humans. A study by [7] Verboom, Kralingen, \& Meier (2004) with urban children in the Netherlands communicated that only $16 \%$ of the children reported going with their families on a field trip to a natural area and over $55 \%$ said they had never visited natural areas or even zoos or botanical gardens. Findings from this study also showed that children play inside their homes most of the time instead of playing outside, contrary to what their parents used to do during their childhood. The authors believed that their study's results could be generalized to other urban areas of Europe with similar cultural, economic and social background.

Many causes could be driving this disconnection between children and the out-of-doors, such as the over-dependence on digital technology, including TVs, video games, and social media ([8] Roberts, Rodkey, Ray, Knight, \& Saelens, 2017). In the same manner, [9] Pergams \& Zaradic (2006) blame the increasing use of video games and Internet as potential reasons for the departure of children from nature. On the other hand, [10] Karsten (2005) highlights the way homes, nowadays, are becoming the leisure space for children due to the increase in consumer goods, namely toys and kids' games. Hence, this home-centered educational culture, associated with the continuous practice of supervising children, is taking them away not only from nature but also from the street, once a meeting place for urban children - from previous generations - living in the same neighborhood.

As an additional factor, [11] Louv (2014) talked about the "Criminalization of Natural Play", where he underscored how the fear of litigation is deterring outdoor play. As a result, the author suggested that, in this era, "[p]arents are afraid to let their kids build a tree house in the backyard. School administrators are afraid to create natural play places". In fact [12] Harper (2017) extensively discusses how the risk-averse Western society attitude is negatively affecting a healthy childhood development. He then recommends the implementation of outdoor educational programs, like Forest and Nature Schools, that could provide children ample opportunities to fully explore "their capacity and curiosity through outdoor risky play" (p. 318).

As for its potential benefits, outdoor experience in nature seems to help students improve their cognitive skills, including their academic performance ([13] Children and Nature Network, 2009; [14] DfES, 2006; [15] Lovell, O'Brien, \& Owen, 2010; [16] Rickinson et al., 2004); imaginative skills and creativity ([14] DfES, 2006; [17] Luchs \& Fikus, 2013; [18] McArdle, Harrison, \& Harrison, 2013; [19] Nedovic \& Morrissey, 2013); and critical thinking ([20] Ernst \& Monroe, 2004). Furthermore, contact with nature was found beneficial in managing attention deficit in children ([21] Kuo \& Taylor, 2004; [22] Wells, 2004).

In the same manner, [23] Kellert (2002) claims for the cognitive, affective and evaluative (values related) potentialities of contact with nature, helping children's development through the promotion of exploration, discovery and imagination. Also [24] Stutchbury (2013) highlights the restorative role of nature in terms of cognition and wellbeing, due to its calming and peaceful effect.

Furthermore, the declining of opportunities to engage with nature during childhood has consequences in aspects other than those directly related to the psychological or physical development of a child, like, for instance, i) a lack of interest in nature, ii) a less commitment to biodiversity preservation, iii) a lack of knowledge of local nature heritage, iv) a lack of perception of the vitality and dignity of other living beings and the continuity between them and the human being; v) a less evaluative capacity of situations of environmental degradation due to the lack of contact with other areas with higher environmental quality (based on ideas proposed by [25] Nabhan \& Trimble, 1994, [26] Pyle, 2002; [23] Kellert, 2002; [27] Kahn, 2002, [28] Consorte-McCrea, Fernandez, Nigbur, \& Morin, 2017).

Besides the significance of the contact with nature on the individuals' wellbeing, there seems to be some benefits related to engaging in activities performed in outdoor settings that are not located in nature. [29] Tovey (2007) highlighted some of the advantages of outdoor activities, independently of the degree of wilderness of the places where they occur. These benefits encompass: i) more space and freedom to try new things; ii) multi-sensorial experiences; iii) a richer context to exploration, curiosity and wonder; iv) the improvement learning; v) the capacity to deal with risks; vi) the development of social skills.

Therefore, it seems that removing children from nature has harmful consequences for them, and contributes to a lack of awareness about the problems faced by the planet. 


\section{METHODOLOGY}

The prevalent decline in the time spent in nature for our children seems to occur in different contexts. However, at least in Portugal, research studies that prove this disconnection and declining are still missing. A pioneer study promoted by [30] Strecht-Ribeiro \& Almeida (2011) with primary school children of the Lisbon region concluded that children's contact where nature is managed, like zoos or gardens, was much more frequent than with natural places. This study, however, was not focused on the types of activities done by children in an outdoor context. Therefore, the present study intends to be complementary to the previous one and its main aims are:

1 to check the frequency of a plethora of activities performed by children in nature, most of them also possible to be performed in different places, independently of their degree of wilderness;

2 to check differences between boys and girls, since outdoor activities can be performed with a different frequency due to cultural reasons.

The study involved 153 urban children, (age average 11.08 and SD 0.944), 87 boys and 70 girls, from 6 state schools with different social backgrounds (low to high socio-economic status) from the Lisbon area, to form a more representative sample. To achieve the above presented aims, a questionnaire was administered containing demographic-related items, such as sex, age and school, and 11 statements related to different outdoor activities. Children had to select the frequency of their performing of each activity, according to a four-point scale: never (1 point), rarely (2 points), sometimes ( 3 points), often (4 points). A total score was then calculated for each child, ranging from 11 to 44 points.

The questionnaire items were adapted from those used in [31] Bixter, Floyd, \& Hammitt (2002) and also included a few activities mentioned by [32] Louv (2010) that were common in previous generations. The activities included were: picking up wild fruits; gardening; climbing trees; catching birds in traps; collecting rocks, minerals and fossils; tracking; visiting farms, zoos and other thematic parks; practising outdoor sports; playing in forested areas; going hunting or fishing with friends and relatives; rappelling and other extreme sports. In this list it is possible to notice the presence of activities that can have a (small) negative impact on nature, as is the case of catching birds of traps. But, its inclusion follows the opinion of [26] Pyle (2002) that even this kind of activities seems to be important to the development of a stronger connection with the natural world.

The four-point scale was considered an interval scale, even knowing that the interval difference between the terms may not be exactly the same, a limitation that is assumed in the analysis. To avoid a great distortion of the analysis considering the mean values obtained, we draw a special attention to the median value. In agreement, and after checking the non-normal distribution of the data, a Mann Whitney test was applied to compare gender scores.

The questionnaire was validated by a group of three experts that considered it adequate for the purpose of the study. The validity and reliability of the scale has been tested. Firstly, the Bartlett's sphericity $(p<0.05)$ and Kaiser-Meyer-Olkin $(0.794)$ tests confirmed the adequacy of a Factor Exploratory Analysis (EFA). The EFA revealed the validity of the instrument and the unifactorial structure of the construct: "Activities in Nature". Furthermore, the reliability was confirmed through the Cronbach's alpha, which value, 0.83 , was considered as very good.

\section{RESULTS}

The results are included in Table 1 , where it is possible to check the frequency with which the participants said to be involved in each of the considered activities and also the total score for the 11 activities. The results of boys and girls are presented separately as well as their statistical comparison after the application of the Mann Whitney test.

The results show that only practising outdoor sports is more frequent in the whole sample and also among boys and girls. Even so, the girls acknowledged that they did this practice sometimes (median 3 ) and the boys often (median 4) with a statistically significant difference between boys and girls is $(p=0.012)$. We speculate that the higher frequency associated with sporting activity could be probably occurring on schools' playgrounds rather than in natural places or other outdoor contexts. Yet, this is only a supposition as it is impossible to confirm that through the collected data. 
Table 1. The results concerning the frequency of each activity and of the total score of all activities by the total sample and by boys and girls separately. The statistical comparison of the results of boys and girls is also included, after the use of the Mann Whitney test.

\begin{tabular}{|c|c|c|c|c|c|c|c|c|c|c|}
\hline \multirow[b]{2}{*}{ Outdoor activities } & \multicolumn{3}{|c|}{ Total Sample } & \multicolumn{3}{|c|}{ Boys } & \multicolumn{3}{|c|}{ Girls } & \multirow{2}{*}{$\begin{array}{c}\text { Mann } \\
\text { Whitney } \\
\text { test }\end{array}$} \\
\hline & Median & Mean & SD & Median & Mean & SD & Median & Mean & SD & \\
\hline Picking up wild fruits & 1 & 1.62 & 0.857 & 1 & 1.71 & 0.930 & 1 & 1.52 & 0.756 & 0.299 \\
\hline Gardening & 1 & 1.54 & 0.760 & 1 & 1.60 & 0.810 & 1 & 1.47 & 0.696 & 0.337 \\
\hline Climbing trees & 2 & 2.03 & 1.063 & 2 & 2.18 & 1.127 & 2 & 1.87 & 0.961 & 0.096 \\
\hline Catching birds in traps & 1 & 1.11 & 0.412 & 1 & 1.16 & 0.513 & 1 & 1.05 & 0.233 & 0.164 \\
\hline $\begin{array}{l}\text { Collecting rocks. } \\
\text { minerals and fossils }\end{array}$ & 2 & 1.86 & 0.964 & 2 & 1.91 & 1.038 & 2 & 1.81 & 0.872 & 0.755 \\
\hline Tracking & 2 & 2.31 & 0.989 & 2 & 2.34 & 0.993 & 2 & 2.27 & 0.991 & 0.729 \\
\hline $\begin{array}{l}\text { Visiting farms. zoos and } \\
\text { other thematic parks }\end{array}$ & 2 & 2.10 & 0.820 & 2 & 2.13 & 0.792 & 2 & 2.07 & 0.856 & 0.706 \\
\hline $\begin{array}{l}\text { Practising outdoor } \\
\text { sports }\end{array}$ & 3 & 3.22 & 0.897 & 4 & 3.37 & 0.865 & 3 & 3.04 & 0.907 & 0.012 \\
\hline $\begin{array}{l}\text { Playing in forested } \\
\text { areas }\end{array}$ & 2 & 2.24 & 0.973 & 2 & 2.25 & 0.998 & 2 & 2.22 & 0.950 & 0.903 \\
\hline $\begin{array}{l}\text { Going hunting or fishing } \\
\text { with friends and } \\
\text { relatives }\end{array}$ & 1 & 1.42 & 0.816 & 1 & 1.55 & 0.927 & 1 & 1.27 & 0.635 & 0.041 \\
\hline $\begin{array}{l}\text { Rappelling and other } \\
\text { extreme sports }\end{array}$ & 2 & 2.24 & 1.101 & 2 & 2.31 & 1.178 & 2 & 2.17 & 1.006 & 0.476 \\
\hline $\begin{array}{l}\text { Total score of the } 11 \\
\text { activities }\end{array}$ & 22 & 21.75 & 5.428 & 22 & 22.55 & 5.78 & 20.50 & 20.80 & 4.847 & 0.080 \\
\hline
\end{tabular}

All the other activities had a very low frequency, the median value oscillating between 1 (never) and 2 (rarely), and without statistically significant differences between boys and girls. The exception is for hunting or fishing with friends and relatives, a more frequent activity among boys $(p=0.041)$. Even so, the median value in both sexes is the same (1), which means that the frequency of this activity is low, even among boys.

Activities like picking wild fruits, catching birds in traps, collecting rocks, minerals and fossils or playing in forested areas, which can be more easily associated with contact with nature, seem to be performed with a very low frequency. And even visiting parks, farms, zoos and other thematic parks obtained the same low frequency, showing that in the present study the tendency of the participants to contact with places where nature is managed is similar to the one in more natural spaces.

The total score of the 11 activities follows the same trend already discussed for each activity. Even so, the mean total score for the boys, i.e., 22.5, was higher than the mean total score for the girls, 20.5. Nevertheless, the difference in the mean of the total scores between genders is not statistically significant $(p=0.080)$. Even so, the results show that boys have a slightly higher tendency to perform outdoor activities.

\section{CONCLUSIONS}

The present study confirmed the trend presented initially during the introduction section of children's departure from nature and from a group of outdoor activities which were, according to [32] Louv (2010), quite common in the past. Therefore, it seems that children nowadays are refraining from performing a myriad of activities common in previous generations, which were responsible for a more frequent and deep contact with nature or, at least, with certain elements of it, like trees, animals or rocks.

The main implication of the results is the need to strengthen outdoor play in different contexts as a part of our children's education. For that, changes in the way parents, schools and policy makers look at these activities are an important step to achieve this aim. 
Parents have to be aware of how important outdoor activities are in children's development, especially in a context of contact with nature and, consequently, to the need of diversifying the kind of places chosen during their leisure time. For instance, [29] Tovey (2007) compared the benefits for children in two settings: gardens and forests. She argues that the natural landscapes are always the best places for children, since they allow the use of children's imagination and creativity in a deeper way, through the manipulation of the features that the environments offer to them. They also bring a richer sensorial experience often in a less supervised environment. Even so, gardens still represent a much better alternative for children if compared to time spent indoors with technological devices.

Also, parents must respond better to the need to expose their children to controlled risk and to perceive it as a necessary element for their growth and own protection. [25] Nabhan \& Trimble (1994) quote a thought of the naturalist Frankin Burroughts who argues that "children need places where they can roughhouse on three limbs and swing on vines without being told that the plants are hands-off" ( $p$. 9). And he concludes: "better to let kids be a hazard to nature and let nature be a hazard to them" ( $p$. 9). More recently, [12] Harper (2017) argues for a change in the way risk is regarded and proposes a slowly return of society to consider risk-taking by children as acceptable and meaningful, especially in the context of outdoor activities in natural places.

In schools, teachers need to be aware of these ideas and strive towards overcoming obstacles hindering the implementation of outdoor activities. These obstacles can be the insensibility of school management staff, the bureaucratic procedures of organizing outdoor activities, costs of travelling, inability to take risks, lack of scientific confidence, lack of time to plan these activities ([33] Almeida \& Vasconcelos, 2013), just to name a few. Normally, the good examples come from the Nordic countries. [34] Sobel (2004) highlights a programme for kindergarten entitled "Outdoors in all weather", of which the main idea was to spend from $60 \%$ to $80 \%$ of the daily time outside the classroom, regardless of the weather. In the assessment of this programme, in addition to its educational potential, the curious fact was that children contracted, on average, fewer infectious diseases, when compared to those who experienced more traditional educational approaches.

On a local level, it would be unfair not to mention a few projects developed recently in Portugal that tried to improve children's contact with nature. The "PREDINATUR project" involved primary school pupils and had precisely the aim of improving this contact with the important dimension of using digital resources and technological devices during outdoor activities in nature to promote aesthetic fruition and enjoyment of nature ([35] Almeida, Rodrigues \& García Fernández, 2017). Also, the Glocal-act Project (Knowing the Global Environment to Act Locally: From Learning in Natural Areas to Urban Intervention) included among its aims a similar approach of the previous project ([36] Almeida, et al. 2018). Both projects were funded by Portuguese supporters but they could only involve a few classes of three state schools in a sporadic and not continued contact with nature. Therefore, more resources and better conditions have to be given to schools for a generalization of this kind of experiences.

Changes in schools should also be thought of in terms of how their playgrounds are conceived. In fact, a study from [37] Martins, Pereira \& Almeida (2016) showed that the majority of the playgrounds in Lisbon schools are traditionally designed, lacking variety and interest, sometimes with tiny gardens only with a decorative purpose. In fact, playgrounds in schools could be improved and be much more interesting places, especially if they include wilder areas conducive for playing and children's exploration.

Finally, it is important to state that the Lisbon region includes several natural areas with a different degree of wilderness. Among them is the urban Monsanto Park located inside the city which is an extraordinary example of an area where a lot of different outdoor activities can be implemented, and it certainly deserves to be more visited by parents and schools. Yet, it is also true that the green reality of the country and of the Lisbon area is not always so positive. The process of urbanization has been in some areas disastrous, with the connivance of local authority. The tiny garden zones in the middle of the extensive urbanization areas essentially aim to make the ventures attractive, giving the illusion of a quality that in fact is lacking and without taking into consideration the real needs of the population in general and our children in particular. That is why, it is important to preserve the green semi-natural areas that still exist in the territory, avoiding their degradation and making them safe spaces for our children to play in a less structured way. This will only be possible provided there is a change of attitude in our policy-makers, as a result of pressure brought to bear by the people. 


\section{ACKNOWLEDGEMENTS}

This study is included in the ANIMALIS project (IPL/2018/ANIMALIS_ESELX), which is funded by the Polytechnic Institute of Lisbon, Portugal.

\section{REFERENCES}

[1] United Nations. "News from Department of Economic and Social Affairs", 16 May 2018, Retrieved from: https://www.un.org/development/desa/en/news/population/2018-revision-of-worldurbanization-prospects.html

[2] S. Kellert, Kinship to Mastery. Biophilia in Human Evolution and Development. Washington: Island Press, 1997.

[3] S. Kellert, Building for Life. Designing and Understanding the Human-Nature Connection. Washington: Island Press, 2005.

[4] R. Clements, "An Investigation of the Status of Outdoor Play," Contemporary Issues in Early Childhood, vol. 5, no. 1, pp. 68-pp. 80, 2004.

[5] UNEP World Conservation Monitoring Centre (UNEP-WCMC). Protected Planet Report 2018. Tracking progress towards global targets for protected areas, 2018, Retrieved from: https://livereport.protectedplanet.net/pdf/Protected_Planet_Report_2018.pdf

[6] S. Cian, S. Cavagna, \& M. Zoccoli, O Desafio de Educar nas Áreas Protegidas. Lisboa: Instituto de Inovação Ambiental, 2001.

[7] J. Verboom, R. Kralingen, \& U. Meier, Teenagers and biodiversity - worlds apart? An essay on young people's views on nature and the role it will play in their future. Wageningen: Alterra, 2004. Retrieved from http://library.wur.nl/WebQuery/wurpubs/fulltext/41890.

[8] J. D. Roberts, L. Rodkey, R. Ray, B. Knight, \& B. E. Saelens, "Electronic media time and sedentary behaviors in children: Findings from the Built Environment and Active Play Study in the Washington DC area", Preventive Medicine Reports, vol. 6, pp.149-pp.156, 2017.

[9] O. Pergams, \& P. Zaradic, "Is love of nature in the US becoming love of electronic media? 16-year downtrend in national park visits explained by watching movies, playing video games, internet use, and oil prices," Journal of Environmental Management, vol. 80, no. 4, pp. 387-pp.393, 2006.

[10] L. Karsten," It All Used to be Better? Different Generations on Continuity and Change in Urban Children's Daily Use of Space," Children's Geographies, vol. 3, no. 3, pp. 275-pp. 290, 2005.

[11] R. Louv, "The criminalization of natural play: It's time to look for solutions", 16 July 2014. Retrieved from: https://www.childrenandnature.org/2014/07/16/overdue-we-need-a-national-conference-onthe-criminalization-of-natural-play-and-a-no-child-left-inside-legal-defense-fund/

[12] N. Harper, "Outdoor risky play and healthy child development in the shadow of the "risk society": A forest and nature school perspective," Child \& Youth Services, vol. 38, no. 4, pp. 318-pp. 334, 2017.

[13] Children and Nature Network. (2008). A report on the movement to reconnect children to the natural world, 2008. Retrieved from https://boktowergardens.org/wp-content/uploads/2016/08/areport-on-the-movement-to-reconnect-children-to-the-natural-world.pdf

[14] Department for Education and Skills (DfES). Learning outside the classroom manifesto. London, UK: DfES, 2006. Retrieved from http://www.lotc.org.uk/wp-content/uploads/2011/03/G1.-LOtCManifesto.pdf

[15] R. Lovell, L. O'Brien, \& R. Owen. Review of the research evidence in relation to the role of trees, woods and forest in formal education and learning. Report to the Forestry Commission, 2010. Retrieved from http://www.forestry.gov.uk/pdf/Education_and_learning_research_review_ 2010.pdf/Sfile/Education_and_learning_research_review_2010.pdf

[16] M. Rickinson, J.Dillon, K. Teamey, M. Morris, M. Y. Choi, D. Sanders, \& P. Benefield, (2004). A review of research on outdoor learning: Executive summary. London, UK: National Foundation for Educational Research and King's College London, 2004. Retrieved from http://www.peecworks.org/peec/peec_research/01795BFA001D0211.0/NFER\%2520Exec\%2520Summary.pdf 
[17] A. Luchs, \& M. Fikus, "A comparative study of active play on differently designed playgrounds", Journal of Adventure Education and Outdoor Learning, vol. 13, no. 3, pp.206-pp.222, 2013.

[18] K. McArdle, T. Harrison, \& D. Harrison, Does a nurturing approach that uses an outdoor play environment build resilience in children from a challenging background? Journal of Adventure Education and Outdoor Learning, vol. 13, no. 3, pp.238-pp.254, 2013.

[19] Nedovic, S., \& Morrissey, A., Calm active and focused: Children's responses to an organic outdoor learning environment. Learning Environments Research, vol. 16, no. 2, pp.281-pp.295, 2013.

[20] J. A. Ernst, \& M. Monroe, The effect of environment-based education on students' critical thinking skills and disposition towards critical thinking. Environment Education Research, vol. 10, no. 4, pp.507-pp. 522, 2004.

[21] F. E. Kuo, \& A. F. Taylor, (2004). A potential natural treatment for Attention-Deficit/Hyperactivity Disorder: Evidence from a national study. American Journal of Public Health, vol. 94, no. 9, pp.1580-pp.1586, 2004.

[22] N. M. Wells, At home with nature: Effects of "greenness" on children's cognitive functioning. Environment and Behavior, vol. 32, no. 6, pp.775-pp.795, 2000.

[23] S. Kellert, "Experiencing Nature: Affective, Cognitive, and Evaluative Development in Children" in Children and Nature (P. H. Kahn \& S. R. Kellert eds.), pp.117-pp.151, Cambridge, Massachusetts: The MIT Press, 2002.

[24] B. Stutchbury, "Wild Wings" in The Rediscovery of the Wild (P. Kahn \& P. Hasbach eds.), pp.71pp.91), Cambridge: The MIT Press, 2013.

[25] G. Nabhan, \& S. Trimble, The Geography of Childhood. Boston: Beacon Press, 1994.

[26] R. Pyle, "Eden in a Vacant Lot: Special Places, Species, and Kids in the Neighborhood of Life" in Children and Nature (P. H. Kahn \& S. R. Kellert eds.), pp.305-pp.327, Cambridge, Massachusetts: The MIT Press, 2002.

[27] P. Kahn, "Children's Affiliations with Nature: Structure, Development, and the Problem of Environmental Generational Amnesia" in Children and Nature (P. H. Kahn \& S. R. Kellert eds.), pp.93-pp.116), Cambridge, Massachusetts: The MIT Press, 2002.

[28] A. Consorte-McCrea, A. Bainbridge, A. Fernandez, D. Nigbur, S. McDonnell, A. Morin, \& O. Grente, "Understanding attitudes towards native wildlife and biodiversity in the UK: the role of zoos" in Sustainable Development Research at Universities in the United Kingdom: Approaches, Methods and Projects (W. L. Filho ed.), pp.295-pp311), New York: Springer, 2017.

[29] H. Tovey, Playing Outdoors: Spaces and Places, Risk and Challenge. London: Open University Press, Mc Graw Hill, 2007.

[30] O. Strecht-Ribeiro, \& A. Almeida, "As Vivências de contacto com a Natureza de Crianças do 1. ${ }^{\circ}$ Ciclo: Implicações para o contexto formal e não formal de aprendizagem" in Atas do XIV Encontro Nacional de Educação em Ciências (L. Leite, et al. eds.), pp.213-pp226, Braga: Instituto de Educação da Universidade do Minho, 2011.

[31] R. Bixter, M. Floyd, \& W. Hammitt, "Environmental Socialization: Quantitative Tests of the Childhood Play Hypothesis," Environment and Behavior, vol. 34, no. 6, pp.795-pp.818, 2002.

[32] R. Louv, Last Child in the Woods. London: Atlantic Books, 2010.

[33] A. Almeida, \& C. Vasconcelos, Guia prática para atividades fora da escola. Lisboa: Fonte da Palavra, 2013.

[34] D. Sobel, Place-Based Education: Connecting Classrooms \& Communities. Great Barrington (Massachusetts): The Orion Society, 2004.

[35] A. Almeida, M. Rodrigues, \& B. García Fernández, "The PREDINATUR Project: Educational Resources for Promoting Pupils' Contact with Nature" in ICER/2017 Proceedings $10^{\text {th }}$ International Conference of Education, Research and Innovation (L. Gómez Chova, A. López Martínez, I. Candel Torres eds.), pp.1195-pp1204, Sevilla, 2017. 
[36] A. Almeida, M. Silva, B. Valente, M. Rodrigues, \& V. Manteigas, "The Project "Knowing the Global Environment to Act Locally: From Learning in Natural Areas to Urban Intervention (Glocal-act)" in ATINER'S Conference Paper Series, Athens, 2018.

[37] I. Martins, C. Pereira, \& A. Almeida, "Potencialidades e utilização do Espaço Recreio: Um estudo em escolas do $1^{\circ}$ Ciclo do Ensino Básico", Revista Electrónica de Enseñanza de las Ciências, vol. 15, no. 1, pp.98-pp.120, 2016. 